\title{
MAKALAH \\ TEKNIK BUDIDAYA TANAMAN PERKEBUNAN \\ TANAMAN TEMBAKAU
}

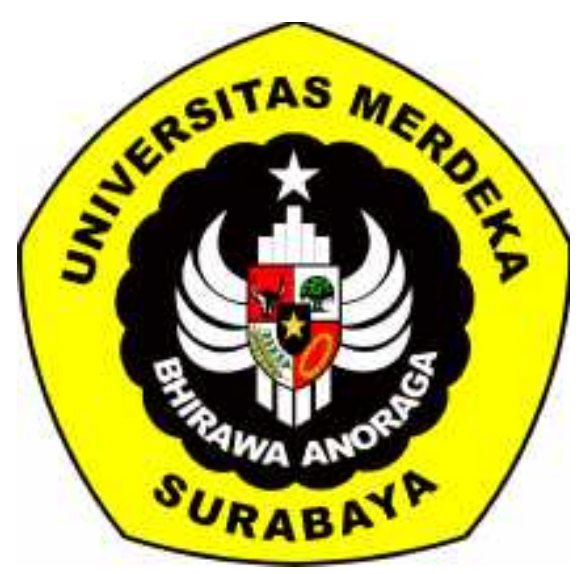

Disusun oleh :

Indriani Puspita Sari

15.542110003

Dosen Pengampu :

Mahrus Ali , S.TP,. M.Agr

Fakultas Pertanian

Program Studi Agroteknologi

Universitas Merdeka Surabaya

Tahun 2017 


\section{BAB 1 \\ PENDAHULUAN}

\subsection{Latar Belakang}

Indonesia merupakan negara yang kaya akan keragaman flora. Iklimnya sangat cocok untuk tumbuh berbagai jenis tanaman. Salah satu tanaman yang dinilai berprospek cerah adalah komoditas perkebunan industri. Secara umum budi daya perkebunan merupakan kegiatan usaha tanaman yang hasilnya untuk di ekspor atau bahan baku industri. Perkebunan telah mampu menunjukan peran dan keuntungannya dalam perekonomian nasional. Penerimaan ekspor komoditas perkebunan pada tahun 2008 mencapai USD 18,85 miliar, pendapatan cukai rokok sekitar Rp 52 triliun, dan pungutan ekspor CPO lebih dari Rp13,5 triliun.

Komoditas perkabunan yang berfungsi sebagai penyedia bahan baku industri dalam negeri contohnya adalah rokok. Rokok merupakan hasil industri dalam negeri yang berasal dari tanaman tembakau. Tembakau merupakan komoditas perkebunan yang mempunyai peranan strategis dalam perekonomian nasional, yakni merupakan sumber pendapatan negara melalui devisa negara, cukai, pajak, serta sumber pendapatan petani, dan dapat menciptakan lapangan kerja. Ditinjau dari aspek komersial, komoditas tersebut merupakan bahan baku industri dalam negeri sehingga keberadaannya perlu dipertahan kan dan lebih ditingkatkan.

Di indonesia, tembakau yang baik (komersial) hanya dihasilkan di daerah-daerah tertentu. Kualitas tambakau ditentukan oleh lokasi dan pengolahannya. Daerah penghasil tembakau adalah sumut(deli), sumatra barat (payakumbuh), bengkulu, sumatra selatan(palembang), jaawa tengah (surakarta, klaten, dieng, kedu, temanggung, parakan, serta wonosobo), dan jawa timur (bojonegoro dan besuki).

Dari segi penerimaan pemerintah terhadap cukai rokok, terlihat bahwa setiap tahun terus meningkat. Pada tahun 1999 besarnya cukai rokok RplO,16 trilyun. Demikian pula dalam bidang perdagangan, pada tahun 1999 devisa dari ekspor rokok dan tembakau mencapai US\$235 juta. Untuk mempertahankan kondisi tersebut di atas diperlukan perhatian pemerintah khususnya dalam upaya menyeimbangkan suplai dan kebutuhan dengan memperhatikan faktor teknis dari pembibitan dan perawatan tembakau lebih di tekankan sebagai salah satu upaya untuk meningkatkan mutu tembakau nasional. 
Penanaman dan penggunaan tembakau di Indonesia sudah dikenal sejak lama. Komoditi tembakau mempunyai arti yang cukup penting, tidak hanya sebagai sumber pendapatan bagi para petani, tetapi juga bagi Negara Tanaman Tembakau merupakan tanaman semusim, tetapi di dunia pertanian termasuk dalam golongan tanaman perkebunan dan tidak ermasuk golongan tanaman pangan. Tembakau (daunnya) digunakan sebagai bahan pembuatan rokok. Usaha Pertanian tembakau merupakan usaha padat karya. Meskipun luas areal perkebunan tembakau di Indonesia, diperkirakan hanya sekitar 207.020 hektar, amun jika dibandingkan dengan pertanian padi, pertanian tembakau memerlukan tenaga kerja hampir tiga kali lipat. Seperti juga ada kegiatan pertanian lainnya, untuk mendapatkan produksi tembakau dengan mutu yang baik, banyak faktor yang harus diperhatikan selain faktor tanah, iklim, pemupukan dan cara panen. Maka dari itu penting mengetahui bagaimana sistem budidaya tanaman tembakau(Hariyadi, Ali, \& Nurlina, 2017).

\subsection{Rumusan Masalah}

Berdasarkan uraian latar belakang diatas maka permasalahan yang dibahas dalam makalah ini adalah mengenai bagaimana sistem budidaya tanaman tembakau.

\subsection{Tujuan}

Adapun tujuan dari penulisan makalah ini adalah untuk menjelaskan tentang sistem budidaya tanaman tembakau. 


\section{BAB 2}

\section{TINJAUAN PUSTAKA}

\subsection{Sistematika Tanaman Tembakau}

Menurut Matnawi (2012) tanaman tembakau dapat di klasifikasikan sebagai berikut :

Divisio : Spermatophyta

Sub divisia : Angiospermae

Class : Dicotyledoneae

Ordo : Personatae

Famili : Solanaceae

Genus : Nicotiana

Spesies $\quad$ : Nicotiana tabaccum L.

\subsection{Biologi Tanaman Tembakau}

Tanaman tembakau berwarna hijau berbulu halus, batang, dan daun diliputi oleh zat perekat. Pohonnya berbatang tegak dengan ketinggian ratarata mencapai $250 \mathrm{~cm}$, akan tetapi kadang-kadang dapat mencapai tinggi sampai $4 \mathrm{~m}$ apabila syarat-syarat tumbuh baik. Umur tanaman ini rata-rata kurang dari 1 tahun. Daun mahkota bunganya memiliki warna merah muda sampai merah, mahkota bunga berbentuk terompet panjang, daunnya berbentuk lonjong pada ujung runcing, dan kedudukan daun pada batang tegak (Abdullah, 1982).

Tanaman tembakau memiliki akar tunggang, jika tanaman tumbuh bebas pada tanah yang subur sepanjang $0,75 \mathrm{~m}$. Selain akar tunggang terdapat bulu-bulu akar dan serabut. Akar tanaman tembakau kurang tahan terhadap air yang berlebihan karna dapat menggannggu akar bahkan tanaman dapat mati (Matnawi, 1997).

Daun tembakau berbentuk lonjong atau bulat, tergantung pada varietasnya. Daun yang berbentuk bulat lonjong ujungnya berbulat runcing, sedangkan berbentuk bulat ujungnya berbentuk tumpul. Daun memiliki tulang-tulang menyirip, bagian tepi daun agak bergelombang dan licin. Ketebalan daun yang berbeda-beda, tergantung varietas budidaya. Daun 
tumbuh berselang-seling mengelilingi batang tanaman. Daun memiliki mulut daun yang terletak merata. Jumlah daun dalam satu tanaman 28-32 helai (Cahyono, 2011).

Bunga tanaman tembakau merupakan bunga majemuk yang tersusun dalam beberapa tandan dan masing-masing tandan berisi samapi 15 bunga. Bunga berbentuk terompet yang panjang. Warna bunga merah jambu sampai merah tua pada bagian atasnya sedangkan yang lain berwarna putih. Bunga tembakau akan mekar secara berurutan dari yang paling tua ke paling muda. Tanaman tembakau dapat mengadakan penyerbukan sendiri walaupun tidak menutup kemungkinan terjadi penyerbukan silang. Bunga ini berfungsi sebagai alat penyerbukan sehingga dapat dihasilkan biji-biji perkembangbiakan ( Maulidiana, 2008). Bentuk buah tembakau seperti telur ayam dengan panjang 1,5-2 cm.warna buah berwarna hijau dan menjadi coklat saat sudah masak. Tingkat kemasakan buah tidak serempak.

\subsection{Syarat Tumbuh Tanaman Tembakau}

Tanaman tembakau tumbuh baik pada ketinggian antara 200-3.000 $\mathrm{m}$ diatas permukaan laut dan membutuhkan curah hujan rata-rata 2000 $\mathrm{mm} /$ tahun dengan suhu udara antara 21-32 derajat $\mathrm{C}$. Batas suhu minimum, yaitu 15 o $\mathrm{C}$ dan suhu maksimum $420 \mathrm{C}$. Suhu ideal pada siang hari adalah 270 C. Curah hujan juga sangat berpengaruh terhadap penentu kualitas dan kuantitas hasil tembakau. Keasaman tanah yang baik untuk tanaman ini adalah $\mathrm{pH}$ antara 5-6. Tanaman tembakau akan tumbuh subur pada tanah gembur, remah, mudah mengikat air, memiliki tata air dan udara yang baik. Tanaman tembakau merupakan tanaman tropis yang dapat hidup pada rentang iklim yang luas. Tekstur tanah lapisan atas yang baik untuk tanaman tembakau adalah lempung berpasir. Tekstur ini mempunyai porsi udara dan air yang optimum bagi pertumbuhan akar tanaman. Karena responnya netral terhadap panjang hari, tanaman tembakau dapat tumbuh dari 600 LU-400 LS. 


\subsection{Varietas Anjuran}

Beberapa jenis tembakau yang di anjurkan untuk di budidayakan :

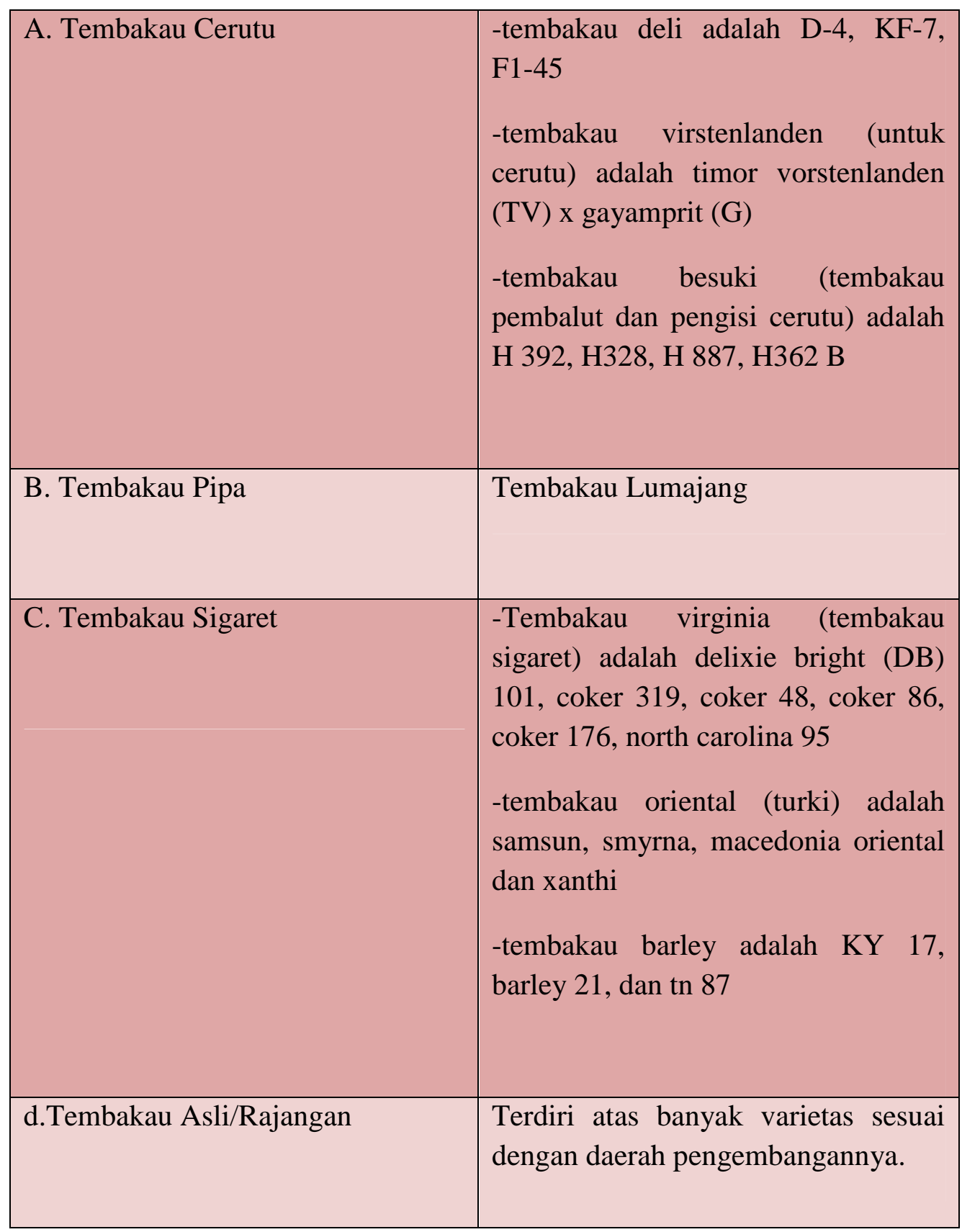




\section{BAB 3}

\section{PEMBAHASAN}

Tembakau adalah komoditi yang cukup banyak dibudidayakan petani. Untuk mendapatkan hasil panen yang optimal para petani tembakau antara lain berusaha membantu meningkatkan produksi secara kuantitas, kualitas dan kelestarian tanaman tembakau. Tanaman tembakau, dengan curah hujan rata-rata $2000 \mathrm{~mm} /$ tahun, Suhu udara yang cocok antara 21-32 derajat $\mathrm{C}, \mathrm{pH}$ antara 5-6. Tanah gembur, remah, mudah mengikat air, memiliki tata air dan udara yang baik sehingga dapat meningkatkan drainase pada pertanaman tembakau.

Kegiatan teknik budidaya tembakau meliputi beberapa jenis kegiatan dengan urutan sebagai berikut.

- Pembibitan, yaitu kegiatan untuk menyiapkan bahan pertanaman.

- Pengolahan tanah merupakan kegiatan untuk menyiapkan media tumbuh tanaman tembakau.

- Penanaman yang meliputi pengaturan jarak tanam, pembuatan lubang tanam dan penanaman.

- Pemeliharaan tanaman yang meliputi penyiraman, penyiangan (pengendalian gulma dan penggemburan), pengendalian hama dan penyakit, pemupukan dan pewiwilan.

- Panen dan penanganan pasca panen hingga hasil tembakau dipasarkan.

Ada bebarapa tahap yang harus di lakukan sebelum melakukan usaha budidaya tanaman tembakau, yaitu perencanaan areal pembibitan dan penanaman tembakau. Dalam tahapan ini dilakukan pengamatan terhadap tempat yang akan digunakan untuk usaha budidaya tanaman tembakau, mencakup kesesuaian topografi, jenis tanah, kondisi iklim dan cuaca yang sesuai dengan musim, perencanaan sarana dan prasaran yang mendukung usaha penanaman tembakau dan beberapa tempat yang sesauai dengan karkteristik dari tanaman tembakau.

\subsection{Pembibitan}

Benih tembakau berukuran sangat kecil sehingga bedangan harus dibuat secermat mungkin. Lahan dicangkul 2-3 kali agar tanah cukup gembur dan cukup terkena sinar matahari dan angin. Kemudian dibuat 
bedengan setinggi 20-30 $\mathrm{cm}$ dan membujur ke utara-selatan. Panjang bedengan $5 \mathrm{~m}$ dan lebar $1 \mathrm{~m}$. Bedengan diberi atap yang terbuat dari jerami, alang-alang, daun kelapa atau plastik yang dapat dibuka dn ditutup. Benih ditabur sekitar $2 \mathrm{~g} / 10 \mathrm{~m} 2$ bedengan. Penaburan benih dapat secara kering dicampur dengan pasir atau abu dapur. Kemudian bedengan ditutup dengan pasir tidak lebih dari $2 \mathrm{~mm}$.

Penyiraman merupakan satu hal penting untuk perawatan pesemaian. Penyiraman dapat dilakukan secara teratur pagi dan sore sejak benih ditabur. Setelah bibit berumur 2-3 minggu, atap perlu dibuka pada pagi hari dan ditutup pada siang hari. Dan pada saat lebar daun sudah $5 \mathrm{~cm}$ maka atap dibuka sepanjang hari. Bibit dapat dipidah setelah umur 35-50 hari.

\subsection{Persiapan lahan}

Pengolahan lahan dimulai dengan cara pembabatan jerami di sawah atau pemabatan tunggul-tunggul pohon tegalan. Pengolahan tanah dapat menggunakan bajak atau cangkul saat tanah masih mengandung cukup banyak air. Setelah dibajak tanah langsung digulud dan siap ditanami.

\subsection{Penanaman}

Penanaman tembakau ditentukan oleh waktu panen. Misalnya, masa panen tembakau terjadi pada pertengahan bilan agustus hingga pertengahan bulan september, penanaman dilakukan peda bulan juni. Namun, untuk tembakau gunung yang tergantung hujan, saat penanaman sebaiknya di ajukan pada bulan mei. Tanaman dapat menghasilkan tembakau mutu tinggi jika paling dikit 1 bulan menjelang panen tidak terkena hujan dan cuaca cerah sampai saat panen.

\subsection{Pemeliharaan}

Pemeliharaan tanaman mutlak dilakukan dalam setiap praktik budidaya karena dapat mempengaruhi kualitas dan kuantitas hasil panen.

\subsubsection{Penyiraman}

Pemberian air pada tanaman tembakau dilakukan secara individual. Penyiraman dapat dilakukan sebanyak 39 kali selama pertumbuhan. Kebutuhan air untuk tembakau sawah dengan tegalan berbeda, yaitu masing-masing memerlukan 0,5 1 dan 21 air per tanaman tiap penyiraman. Intensitas penyiraman setara dengan $194 \mathrm{~mm}$ dan $52 \mathrm{~mm}$ air untuk masingmasing tembakau tegalan dan sawah. 


\subsubsection{Pendagiran, Pembumbunan, Dan Penyiangan}

Tembakau gunung dan tegal ditanam lansung di atas guludan. Tanaman didangir setelah umur tiga minggu. Sambil didangir dan dibumbun, dilakukan penyiangan gulma. Tindakan tersebut diullang lagi saat tanaman berumur lima minggu dan terakhir pada saat umur tujuh minggu.

\subsubsection{Pemupukan}

Pemupukan pada tanaman tembakau disesuaikan dengan kandungan unsur hara yag ada pada tanah dan kebutuhan tanaman. Pemberian pupuk N dilakukan 2 kali, yaitu setengah dosis pada umur satu minggu dans setengah dosis lainnya diberikan pada umur tiga minggu . pemberian pupuk dengan cara memasukan pupuk ke dalam lubang yang dibuat dengan tugal(Ali, 2015).

\subsubsection{Pemangkasan}

Saat mulai keluar bunga, tanaman perlu dilakukan pemangkasan. pemangkasan dilakukan dengan memangkas 3 daun di bawah daun bendera sehingga akan dihasilkan 11-13 daun produksi. Pemangkasan dilakukan untuk mengalihkan pertumbuhan bunga dan buah ke arah pertumbuhan daun-daun atas dapat tumbuh tebal dan besar.

\subsubsection{Penunasan}

Tembakau yang sudah di pangkas akan tumbuh tunas lateral. Dengan adanya tunas tersebut, energi pertumbuhan akar terkuras. Untuk mengefektifkan pertumbuhan maka tunas lateral harus dibuang. Penunasan dilakukan setiap tiga minggu sekali.

\subsubsection{Pengendalian Hama dan penyakit}

\subsubsection{Hama}

Hama yang sering ditemukan di areal pertanaman tembakau antara lain:

\section{- Ulat Pupus Tembakau}

Hama ulat pupus termasuk lepidoptera (noctuidae). Gejala yang ditimbulkan berupa lubang-lubang pada daun tembakau karena ulat memakan pupus dan daun di atas.

\section{- Ulat Grayak (Spodoptera litura)}

Ulat ini menyerang pembibitan dan penanaman tanaman tembakau. Ulat memakan daun pada malam hari. Serangannya menggerombol dan 
menyebabkan lubang-lubang pada daun. Kerusakan padapembibitan hingga $80-100 \%$.

\section{- $\quad$ Kutu Tembakau (Myzus persicae (sulzer))}

Kutu tembakau termasuk homoptera (aphididae). Hama ini menyerang di pembibitan dan pertanaman. Kutu ini menyerang tembakau dengan cara mengisap cairan daun sehingga pertumbuhan tanaman terhambat. Kutu menghasilkan embun madu yang menyebabkan daun menjadi lengket dan ditumbuhi cendawan berwarna hitam. Tingkat kerusakan menimbulkan kerugian hingga 22-28\%.

\subsubsection{Penyakit}

Penyakit yang sering ditemukan di areal pertanaman tembakau antara lain:

\section{- Penyakit Rebah Semai}

Penyakit ini sering dijumpai pada persemaian di lahan sawah. penyebabnya adalah pythium spp., sclerotium sp., dan rhizoctonia sp., pangkal bibit yang terserang berlekuk, seperti terjepit, busuk, berwarna cokelat hingga akhirnya bibit roboh. Serangan pada bibit yang lebih tua atau yang baru dipindah menyebabkan pertumbuhan terhambat, daun menguning, layu, pangkal batang berlekuk, busuk, berwarna coklat, dan akhirnya mati.

\section{- Penyakit Mosaik Tembakau}

Penyakit ini disebabkan oleh virus TMV (tobacco mozaic virus) . Daundaun muda yang terseerang menunjukan gejala vein clearing. Yaitu penjernihan warna tulang daun. Bentuknya sering melengkung. Jika daundaun bertambah umurnya, muncul bercak-bercak kuning dan akhirnya menjadi bercak-bercak klortik yang tidak teratur sehingga daun tampak belang.

\subsection{Panen}

Tembakau dipanen dalam waktu relatif singkat dibandingkan dengan tanaman perkebunan lainnya. Pemanenan tergantung warna daun, waktu pemanenan, dan teknik pemanenan. Secara umum tembakau dipanen satu kali untuk seluruh daun.

Daun tembakau dipetik jika telah cukup masak. Ciri daun yang cukup masak ditandai dengan perubahan warna hijau kekuningan dan ujung daun melengkung dan sedikit mengering pada ujung. Jika daun kurang atau kelewat masak akan mempengaruhi mutu dari tembakau. Oleh karena itu , panen dilakukan bertahap sesuai dengan tingkat kemasakan daun. 
Pemetikan dilakukan pada pagi hari setelah embun menguap atau sore hari. Hasil pemetikan harus langsung dibawa ke tempat teduh atau di gedung penglahan dengan hati-hati untuk meminimalisasi kerusakan yang mengakibatkan kerusakan secara mekanis, fisik maupun fisiologi.

\subsection{Pascapanen}

Setelah dilakukan sortasi awal berdasarkan kualitasnya, proses selanjutnya adalah pengeringan (curing). Berdasarkan tujuan dan jenis pengeringannya, ada empat cara pengeringan yaitu air curing, sun curing, flue curing, fire/smoke curing.

Tembakau yang dikeringkan dengan cara air curing umumnya jenis tembakau cerutu yang dikerjakan oleh rakyat. Pengeringan dengan cara sun curing biasanya dilakukan pada tembakau jenis turki atau tembakau pipa lumajang. Sistem pengeringan flue curing biasanya digunakan pada tembakau virginia. Dan cara pengeringan dengan cara fire/smoke curing biasanya dilakukan apabila kondisi cuaca tidak mendukung untuk melakukan pengeringan dengan cara sun curing.

Dalam tahapan-tahapan tersebut diatas sangatlah penting untuk memenuhi kebutuhan dalam melaksanakan usaha budidaya pembibitan dan penanaman tembakau agar pelaksanaannya berjalan sesuai dengan perencaan yang diinginkan. Apabila tahapan-tahapan tersebut diatas tidak terpenuhi salah satu atau sebagian dari tahapan budidaya tembakau maka akan mengakibatkan terjadinya kegagalan dalam budidaya tembakau yang masih awal.

Inti dari sistem budidaya tanaman tembakau sama dengan sistem budidaya untuk tanaman perkebunan lainnya yaitu terdiri dari pembibitan, penyiapan lahan, penanaman, pemeliharaan, panen dan pasca panen. Hanya saja pada budidaya tanaman tembakau ini yang harus diperhatikan adalah saat pemangkasan. Hal tersebut menjadi penting karena pemangkasan nantinya akan sangat mempengaruhi produktivitas daun tembakau. 


\section{BAB 4}

\section{KESIMPULAN DAN SARAN}

\subsection{Kesimpulan}

Dari hasil pembahasan makalah ini maka dapat disimpulkan bahwa:

1. Tanaman karet merupakan tanaman perkebunan sebagai bahan baku industri untuk produk Rokok yang memiliki nilai ekonomis sangat menjanjikan.

2. Sistem budidaya tanaman tembakau sama dengan sistem budidaya untuk tanaman perkebunan lainnya yaitu terdiri dari pembibitan, penyiapan lahan, penanaman, pemeliharaan, panen dan pasca panen.

3. Hal yang sangat penting untuk diperhatikan dalam budidaya tanaman tembakau adalah proses pemangkasan.

\subsection{Saran}

Tanaman tembakau akan berproduksi tinggi apabila dikelola dengan baik dan benar. Untuk itu disarankan agar para mahasiswa umumnya dan para petani dan pelaku perkebunan tembakau khususnya dapat memahami bagaimana sistem pengelolaan perkebunan tembakau yang baik dan benar. 


\section{REFERENCE}

Abdullah, Ahmad dan Soedarmanto. 2009. Budidaya Tembakau. CV Yasaguna. Jakarta

Cahyono, B. 2011. Botani Tanaman Tembakau ( Nicotinae Tabaccum L. ). Kanisius. Yogyakarta.

Firmansyah, H. 2010. Teknik Budidaya Tanaman Tembakau http://binaukm.com/2010/05/teknik-budidaya-tanaman-tembakau/. Diakses pada tanggal 06 Februari 2015.

Hariyadi, B. W., Ali, M., \& Nurlina, N. (2017). Damage Status Assessment Of Agricultural Land As A Result Of Biomass Production In Probolinggo Regency East Java. ADRI International Journal of Agriculture, 1(1).

Hanum, C. 2008. Teknik Budidaya Tanaman. Departemen Pendidikan Nasional, Jakarta.

Maudidiana, N. 2008. Identifikasi Sistem Budidaya Tembakau Delli. Departemen Teknologi Pertanian, Fakultas Pertanian, Universitas Gadjah Mada. Yogyakarta

Matnawi, M. 2012. Sistematika Tanaman Tembakau ( Nicotinae Tabaccum L. ). Universitas sumatra utara.

Nasution, H. 2009. Pengendalian Penyakit Rebah Semai Pada Persemaian Tanaman TEmbakau Deli (Nicotiana Tabaccum L.) Dengan Memanfaatkan Zat Ekstraktif Kulit Mindi (Melia Azedarach Lin.). Departemen Teknologi Pertanian, Fakultas Pertanian, Universitas sumatra utara.

Riajaya. Prima. 2010. Upaya Adaptif pada Tanaman Tembakau dan Serat Menghadapi Musim Kemarau Basah 2010 
